\title{
New data on the genus Luidia Forbes, 1839 (Asteroidea Lu- idiidae) from the gulf of Oman and first record of Luidia mac- ulata Müller et Troschel, 1842 in this region
}

\author{
Yaser Fatemi ${ }^{*}$ \& Ruhallah Fatemi \\ ${ }^{1}$ Young Researchers and Elite Club, Bandar Abbas Branch, Islamic Azad University, Bandar Abbas, Iran \\ ${ }^{2}$ Physiology Research Center (PRC), Ahvaz Jundishapur University of Medical Sciences, Ahvaz, Iran \\ *Corresponding author, e-mail: Y.fattemi@gmail.com
}

ABSTRACT

KEY WORDS
As a part of the research program about echinoderms of the Gulf of Oman, Luidia maculata Müller et Troschel, 1842, and L. hardwicki Gray, 1840 (Asteroidea Luidiidae) were collected from the sandy shores of Chabahar Bay along the north part of the gulf during the period from 2015 to 2016. Here, L. maculata is recorded for the first time from the Gulf of Oman and Iranian waters. Luidia hardwicki has been previously reported from this area. Details concerning the identification and distribution range of these species are provided.

Received 25.04.2018; accepted 02.06.2018; printed 30.06.2018; published online 05.07.2018

\section{INTRODUCTION}

Luidia Forbes, 1839 (Asteroidea Luidiidae), with 50 known species and its wide distribution in the tropical and subtropical waters is the only valid genus of Luidiidae Sladen, 1889, the smallest family in the asteroidean (Clark \& Mcknight, 2000; Mah \& Blake, 2012; Kim et al., 2017). They live on the muddy or sandy sediments of substrates (Sloan, 1980).

Members of the Luidiidae Family are identified by having five to nine flat and straplike arms and by the presence of Superambulacral plates and paxillate abactinal surface. In the Luidiidae Family, the lateral side of the body, distinguished by just an inferomarginal plate and supero-marginals plates, are not distinguishable from the paxillae (Clark \& Rowe, 1971).

Asteroidean specimens have been less studied in the gulf of Oman. To date, 6 asteroid species: Astropecten phragmorus Fisher, 1913, A. polyacan- thus Müller et Troschel, 1842, A. hemprichi Müller et Troschel, 1842, A. indicus Döderlein, 1888, Aquilonastra burtonii Gray, 1840, and L. hardwicki Gray, 1840 have been reported from Iranian waters of the gulf of Oman (Khaleghi, 2010; Esfandiarpour, 2014; Panahloo, 2015).

The intertidal benthic fauna of the Iranian coasts along the Gulf of Oman were studied as a part of a research project covering the coastal waters of Jask, Chabahar Bay, and Gwatr Bay. As result, L. maculata and L. hardwicki were collected at low tide from the sandy shores of Chabahar Bay. Luidia hardwicki has been previously reported from the Cabahar Bay (Esfandiarpour, 2014). Because of presence of $L$. maculata in the adjacent waters of the gulf of Oman (Mortensen, 1940; Clark \& Rowe, 1971; Liu, 2008; Price, 1983), observation of this species in this region was predictable. This is the first record of L. maculata from the Gulf of Oman and also Iranian waters. 


\section{MATERIAL AND METHODS}

This study has been conducted along the Iranian waters of the Gulf of Oman. Three locations were selected as sampling sites: Qwatr Bay $\left(25^{\circ} 08^{\prime} \mathrm{N}\right.$, $\left.61^{\circ} 29^{\prime} \mathrm{E}\right)$, Chabahar Bay $\left(25^{\circ} 19^{\prime} \mathrm{N}, 60^{\circ} 37^{\prime} \mathrm{E}\right)$, and Jusk $\left(25^{\circ} 35^{\prime} \mathrm{N}, 58^{\circ} 02^{\prime} \mathrm{E}\right)$ (Figure 1). Specimens were collected from the sandy shores of Chabahr Bay at low tide by hand. Chabahar Bay is located in the north part of the Gulf of Oman along the Iranian waters. In order to keep the specimens alive after the sampling, they've been transported to the laboratory. The samples imaging has been done by digital camera and light microscope. For long time preservation, $75 \%$ ethanol has been used. Specimens were carefully examined and taxonomic studies were performed by following the identification key of James \& Pearse (1969), Clark \& Rowe (1971), Price (1983), and VandenSpiegel et al. (1998).

The examined materials is deposited at the Zoology Museum of Chabahar Maritime University, Iran.

\section{RESULTS}

\section{Systematics}

Classis ASTEROIDEA de Blainville, 1830

Ordo PAXILLOSIDA Perrier, 1884

Familia LUIDIIDAE Sladen, 1889

Genus Luidia Forbes, 1839

\section{Ludia maculata Müller et Troschel, 1842}

EXAMINED MATERIAL. Two adult specimens of $L$. maculata were collected in October 2015 and November 2016 from Chabahar Bay. 2015 specimen with seven and 2016 specimen with six arms.

DESCRIPTION. Ludia maculata is a large species $(\mathrm{R} / \mathrm{r}=7.7$ to 8.1 ) with 6 to 7 (in this study) large, flat, and strap-like arms. Disc small and madreporite covered by paxillae. Abactinal paxillae with eight to twenty short central spinelets and about twenty-five to thirty for more slender peripheral spinelets. The paxillae that are located in midarm are more irregular and smaller and have fewer spinelets than the lateral ones. Large inferomarginal plates with 3 to 5 short spines and numerous spinelets. Adambulacral plate with 3 curved and flatted spines. Ludia maculata has a bold black mottled coloration on the dorsal surface of the body; ventral side whitish. This pattern coloration retained in the preserved specimens. There are no large bivalve pedicellariae near the mouth (Fig. 2).

Distribution. West Indian ocean, East Africa and Madagascar, North Australia, China and South Japan (Clark \& Rowe, 1971), Singapore (VandenSpiegel et al., 1998), Thailand (Putchakarn \& Sonchaeng, 2004), Red Sea (James \& Pearse, 1969), Arabian Sea (Parameswaran et al., 2017), Persian Gulf (Mortensen, 1940; Price, 1983), and Pakistan (Haque, 1969).

Remarks. Specimens were collected from the intertidal sandy-gravel shores of Chabahar Bay. In this research, a very rare form of $L$. maculata (with 6 arms) was found in the sampling site. This is the first report of L. maculata from the Gulf of Oman and also Iranian waters.

\section{Luidia hardwicki Gray, 1840}

EXAMINED MATERIAL. About 20 specimens of $L$. hardwicki (all of them with 5 arms) were found in the sandy shores of Chabahar Bay at low tide (2015 to 2016, legit Yaser Fatemi).

DESCRIPTION. A medium sized asteroid species $(\mathrm{R} / \mathrm{r}=5.2)$ with moderately large, flat, and straplike arms (five); Disc small and madreporite covered by paxillae. Preserved specimens pinkish in color; there are no marked color pattern on the dorsal surface body; abactinal paxillae with six to fifteen subequal, blunt-tipped, central spinelets, and with thirteen to twenty-three more slender peripheral ones. Mid-arm paxillae are more irregular and smaller, and have fewer spinelets than the peripheral ones. Large slender pedicellariae on the outer part of some adambulacral plates; a single slender spine and numerious smaller spines encircled the inferomarginal plates. Large bivalve pedicellariae located near the mouth (Figure 3).

Distribution. West Indian Ocean, North Australia, China, and South Japan, Red Sea (Clark \& Rowe, 1971), Singapore (VandenSpiegel et al., 1998), Thailand (Putchakarn \& Sonchaeng, 2004), Arabian Sea (Parameswaran et al., 2017), Persian 


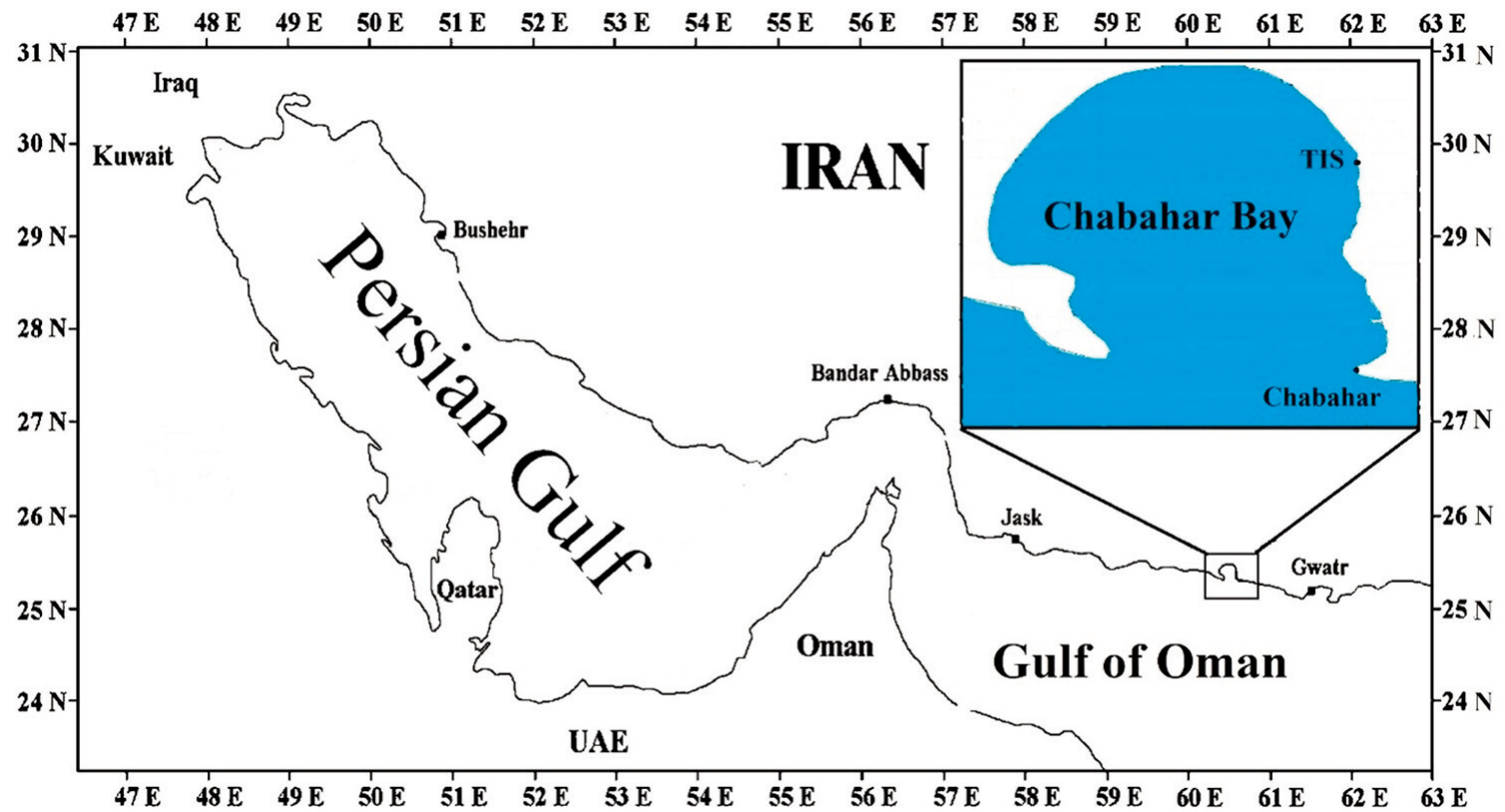

Figure 1. Map of the sampling site.

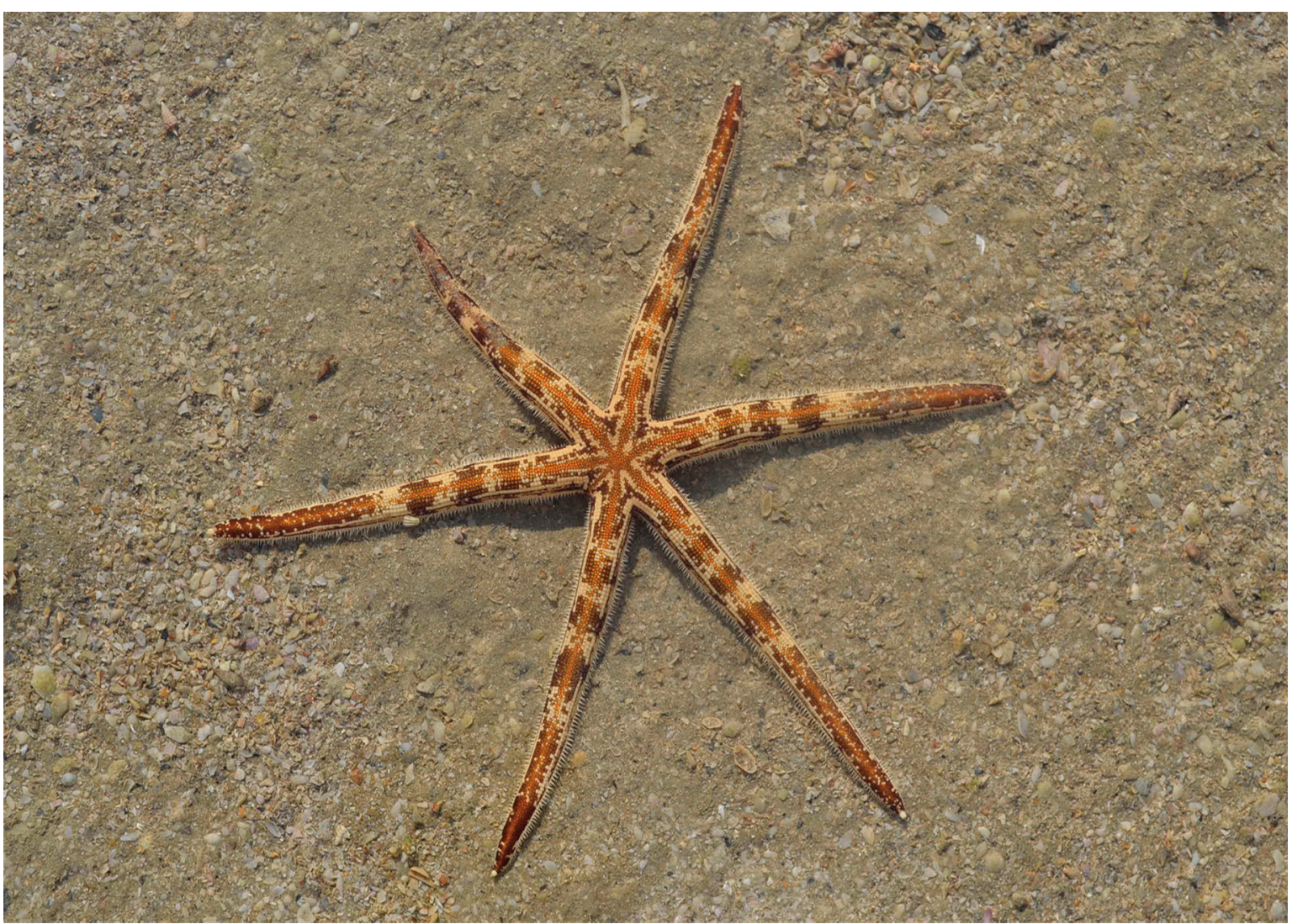

Figure 2. Living specimen of Ludia maculata Müller \& Troschel, 1842, in the sampling site, Chabahar, Iran, Gulf of Oman. Frontal view. Photo credit: Yaser Fatemi. 
Gulf (Mortensen, 1940; Price, 1981), and the Gulf of Oman (Esfandiarpour, 2014).

REMARKS. Luidia hardwicki has been previously reported from the gulf of Oman by Esfandiarpour (2014).

\section{Key to the species of Luidia genus known from the Gulf of Oman}

1. Large specimens with 6 to 7 arms (up to 9); bold black mottled coloration on the dorsal surface of the body; up to twenty central spinelets can be seen for each abactinal paxillae and up to thirty for peripheral ones; there are no large bivalved pedicellariae in the adoral margin of oral plates.

Ludia maculata Müller et Troschel, 1842

2. Specimens with five arms (rarely 6); without marked color pattern on the dorsal surface of the body; abactinal paxillae with six to fifteen subequal, blunt-tipped, central spinelets, and with thirteen to twenty-three more slender peripheral ones. Pinkish in color Luidia hardwicki Gray, 1840

\section{DISCUSSION AND CONCLUSIONS}

Luidia maculata and L. hardwicki of the Luidiidae family were collected from October 2015 to November 2016 by hand in the intertidal waters of the Iranian costs of the Gulf of Oman. Luidia maculata is an indo-pacific species that lives in sandy sediments of substrate. It can be easily distinguished from the related species by the number of arms (usually 7 and very rarely 6) and the bold black mottled coloration of the back (Price, 1983).

Luidia maculata previously reported from the Persian Gulf and Arabian Sea (Mortensen, 1940; Haque, 1969; Clark \& Rowe, 1971; Price, 1983). Therefore, the presence of this species in the gulf of Oman was predictable. Price (1983) reported $L$. maculata (7 specimens) from the subtidal sand and grass beds at 5-11 m depth of Dammam Channel and Tarut Bay (Persian Gulf). Mortensen (1940)

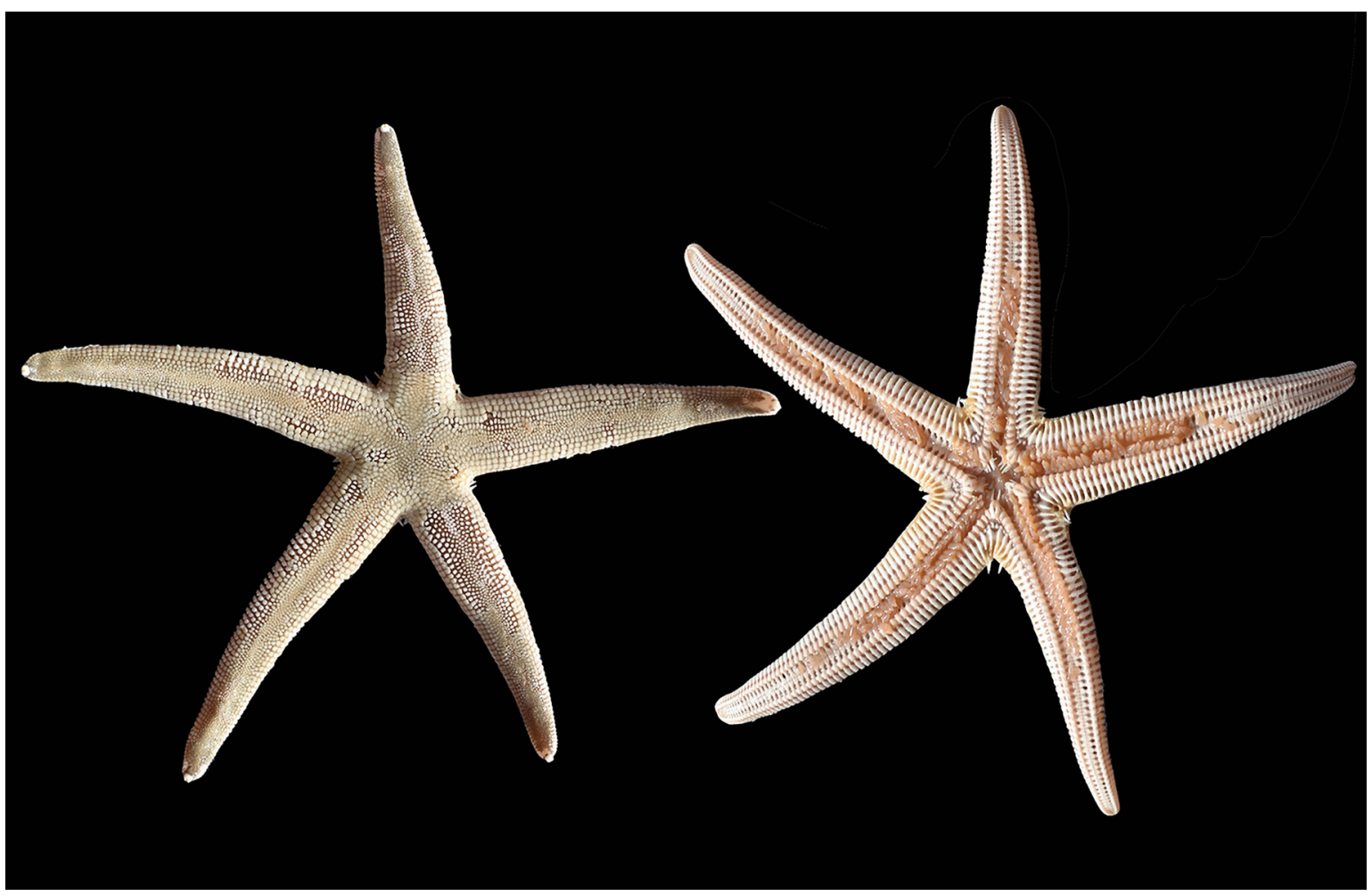

Figure 3. Preserved specimen of Luidia hardwicki Gray, 1840, in aboral view (left) and oral view (right). Chabahar, Iran, Gulf of Oman. Frontal view. Photo credit: Yaser Fatemi. 
collected three specimens of L. maculata at $33 \mathrm{~m}$ depth of northeast of Bahrain (Persian Gulf). Luidia maculata was reported for the first time in Pakistan in the survey study of Haque (1969).

Luidia harwicki is a common species of Luidiidae that has been recorded from the northwest of the Indian Ocean (Mortensen, 1940; Clark \& Rowe, 1971; Esfandiarpour, 2014; Parameswaran et al., 2017). It can be easily observed on the sandy shores of Chabahar Bay at low tide.

Chabahar Bay is semiclosed, with gentle slope and sandy beach that has favorable conditions for the survival of echinoderms. Both species cannot be found in the Jusk and Gwatr Bay. It can be related to the extreme waves in the coast of Jusk and to muddy sediment of mangrove forest of Gwatr Bay (Fatemi et al., 2015). Unlike the other studies, L. maculata was collected in the intertidal zone of Chabahar Bay at low tide. According to the literature, it can be said that L. maculata is a moderately rare asteroid species in the northwest part of Indian Ocean. However, L. hardwicki is a common asteroidae in this region.

This study represents the first record of L. maculata in the Gulf of Oman and Iranian waters. Cabahar Bay is the northernmost records in the Indian Ocean for the distribution range of L. maculata. From the family of Luidiidae, L. prionota Fisher, 1913, has been recorded from the Persian Gulf, Red Sea, and Arabian Sea (Mortensen, 1940; Clark \& Rowe, 1971). Thus, the presence of this species in the Gulf of Oman can be predictable.

More studies are required to find the L. prionota and other asteroidean species of the Gulf.

\section{ACKNOWLEDGEMENTS}

The authors are deeply grateful to Andrew R.G. Price (School of Life Sciences, University of Warwick, Coventry, CV4 7AL, UK) and Mohammad Javad Malek-hosseini (Department of Biology, Biotechnical Faculty, University of Ljubljana, Ljubljana, Slovenia) for helpful comments on the first version of the manuscript.

\section{REFERENCES}

Clark A.M. \& Rowe F.E.W., 1971. Monograph of shal- low-water Indo-West Pacific echinoderms. British Museum Press, 238 pp.

Clark H.E.S. \& Mcknight D.G., 2000. The marine fauna of New Zealand: Echinodermata: Asteroidea (Sea Stars), Order Paxillosida. National Institute of Water and Atmospheric Research (NIWA) Biodiversity Memoires, 116: 14-135.

Esfandiarpour F., 2014. Sea star (Echinodermata) species diversity and distribution in the south-east of Iran (Gulf of Oman). MSc, Chabahar Maritime University, Chabahar, Iran.

Fatemi Y., Attaranfariman G. \& Stara P., 2015. Sculpsitechinus iraniensis n. sp. (Clypeasteroida Astriclypeidae), from Chabahar Bay, southeast coast of Iran. Biodiversity Journal, 7: 395-944.

Haque M.M., 1969. Echinoderms of Pakistan coast. Zoological survey of Pakistan 1: 27-38.

James D.B. \& Pearse J.S., 1969. Echinoderms from the Gulf of Suez and the northern Red Sea. Journal of the Marine Biological Association of India, 11: 78-125.

Khaleghi M., 2010. Echinoderms species of Chabahar Bay. MSc, Khoramshahr Marine Science and Technology University, Khoramshahr, Iran.

Kim D., Kim M. \& Shin S., 2017. A newly recorded Sea Star of the genus Luidia (Asteroidea: Paxillosida: Luidiidae) from the Korea Strait, Korea. Animal Systematics, Evolution and Diversity, 33: 131-135. DOI: 10.5635/ASED.2017.33.2.061

Liu J.Y., 2008. Checklist of Marine Biota of China Seas. China Science Press, 1267 pp.

Mah C.L. \& Blake D.B., 2012. Global diversity and phylogeny of the Asteroidea (Echinodermata). PLoS ONE, 7:e35644. DOI: 10.1371/journal. pone. 0035644

Mortensen T.H., 1940. Echinoderms of the Iranian Gulf, Asteroidea, Ophiuroidea and Echinoidea. In: K. Jessen \& R. Spirck (Eds.), Danish Scientific Investigations in Iran, Part II. Copenhagen: Einar Munksgaard, pp. 55-110.

Panahloo N., 2015. Diet of three Sea star (Echinodermata: Asteroidea) from Chabahar coastal area. MSc, Chabahar Maritime University, Chabahar, Iran.

Parameswaran U.V., Sanjeevan V.N., Abdul Jaleel K.U., Jacob V., Gopal A., Vijayan A.K. \& Sudhakar M., 2017. An updated checklist of echinoderms of the southeastern Arabian Sea. Marine Biodiversity, 22: $1-23$.

Price A.R.G., 1983. Echinoderms of Saudi Arabia. Echinoderms of the Arabian Gulf coast of Saudi Arabia. Fauna of Saudi Arabia, 5: 28-108.

Putchakarn S. \& Sonchaeng P., 2004. Echinoderm Fauna of Thailand: History and Inventory Reviews. ScienceAsia, 30: 417-428.

Sloan N.A., 1980. The arm curling and terminal tube-foot responses of the asteroid Crossasterpapposus (L.). 
Journal of Natural History, 14: 469-482.

VandenSpiegel D., Lane D.J.W., Stampanato S. \& Jangoux M., 1998. The asteroid fauna (Echinodermata) of Singapore, with a distribution table and an illustrated identification to the species. Raffles Bulletin of Zoology, 46: 431-470. 